\title{
Communication Abilities of Autistic Children in Social Interaction
}

\author{
Ria Dwi Ismiarti ${ }^{1}$, Munawir Yusuf ${ }^{2}$, Zaini Rohmad ${ }^{3}$
}

\begin{tabular}{l} 
ARTICLE INFO \\
\hline Article History: \\
Received 01.10.2018 \\
Received in revised form \\
02.01 .2019 \\
Accepted \\
Available online 01.04.2019
\end{tabular}

\section{INTRODUCTION}

Autism spectrum disorders include social, language and behavioral function. Autism varies from minimal to very expressive expression. Changes in symptoms of autism can be predicted on a periodic basis. For example, echolalia during childhood may be pronounced in hard pronunciation and verbally joking until childhood or adolescence. While the prognosis for children with autism are very dominant impact on the degree of expression and degrees of developmental disabilities (Ginintasasi, 2016).

As quoted by Rahayu (2014) the term autism comes from the word autos meaning self ism mean a stream; when combined mean a notion that is interested only in a stream; when combined mean a notion that is interested only in his own world.

Autistic children have difficulty communicating in the language, even in sign language or gesture. They are difficult to convey messages and receiving messages. Communication and language of autistic children is very different from most kids his age. Autistic children understand the difficulties in communication both verbal and non-verbal (Yuw ono, 2012).

Ability to communicate and the language is an important part of everyday life. By having the ability to communicate and speak good, the child can understand and convey information, ask for the preferred, express thoughts and express or express a desire to meet the needs (Yuw ono, 2012).

Communication is a prerequisite for the occurrence of an interaction. If the communication is bad then the interaction is also bad. Kanner (1985) explains that barriers to social interaction in children with autism do not necessarily make them do not make interaction at all.

According to Miller in Nurudin (2017: 39) communications are situations that allow a source transmitting a message to a recipient consciously to influence behavior. Communication is divided into two, namely verbal communication that uses words, both spoken and written. While the non-verbal communication is communication is communication in addition to the spoken and written language (Nurudin, 2017).

According Empowerment Agency for Quality Assurance and Educational Resources (Delphie, 2009) social interaction in children with autism are divided into three types, namely aloof or aloof, passive and active, but in a strange way (active but odd). Social interaction useful to study and learn a lot of problems in the community (Soekanto and Sulistyow ati, 2013).

With a variety of character possessed by children with autism, children with autism require special education services. Such as inclusive education, inclusive education is an ideology in organizing the implementation of education, in which children with special needs acquire education services along with other kids in good quality and in accordance with their needs and is done in the same learning environment

1; bukuusangria@gmail.com, orcid.org/0000-0001-8380-1994;

3;orcid.org/0000-0002-6179-5666

2; orcid.org/0000-0001-9758-6172;

1,2,3,Sebelas Maret University 
Ismiarti,R.D., Yusuf,M. \& Rohmad,Z. (2019). Communication abilities of autistic children in social interaction .International Journal of Educational Research Review, 4(2),172-177.

(Agustin, 2016). Inclusive is the unification of disabled children (with barriers or disabilities) in a realistic and comprehensive way into a comprehensive educational life program (Smith, 2014).

\section{Situation of the Problem}

Several studies have investigated the attitudes of teachers and prospective undergraduate teachers tow ards teaching profession. However, there are limited studies regarding relationships between various variables and attitudes towards teaching profession among the students and graduates who receive pedagogic training (Agustin, 2016).

Still according to Agustin (2016) in order to meet the requirements for teaching profession, one has to have positive attitudes towards the profession. Carrying out the teaching profession with sympathy is an important factor for being successful in the profession. Therefore, in order to provide opportunities to develop positive attitudes towards teaching profession, and in order to contribute to the efforts for developing and enhancing the pedagogic training, it is important to learn about the attitudes towards teaching profession among the students/graduates who did not prefer teacher education programs, but later took pedagogic training in order to be assigned as teachers.

\section{Aim of the Study}

Aim of the present study is to determine attitudes towards teaching profession among the students who receive pedagogic training in order to be assigned as teachers. Within the framew ork of this general aim, answers to the following questions have been sought: Do the attitudes tow ards teaching profession among the students who receive pedagogic training significantly change regarding the variables; (1) gender, (2) level of education (grade or status for graduation), (3) department in which one has took education / graduated from, (4) faculty/school in which one has took education / graduated from.

\section{METHOD}

The study was conducted in three inclusive schools in Semarang, with research subjects are students with autism and special assistant teacher. The study was conducted to reveal the communication skills of children with autism in social interaction. The study focused on aspects of verbal communication skills, nonverbal communication, social interactions positive and negative social interactions.

This type of research is qualitative analysis with case study approach. The case studies are real-life research exploring every detail through the collection of the data involving multiple sources of reliable information, it is revealed by Creswell (2015).

According to Creswell (2015) case study design used in this research is a case study for analyzing and comparing the compound of cases or problems in two different places. And this study aims to determine the form of communication autistic children in social interaction in inclusive school.

The data collected in this study is qualitative data. Data collection techniques used are:

1. Interview

According to Denzin and Lincoln (2011) interview the techniques of data collection used to explore and expand the information disclosed pent using open-ended questions. In-depth interviews in this research is addressed to parents of autistic students and special assistant teachers with interview guides open questions aimed at obtaining depth of data on how ability to communicate autistic students in social interaction in inclusive school.

2. Observation

Observations conducted by researchers to observe you're the ability to communicate autistic students in social interaction in inclusive school.

3. Literature Review

To collect the data and theory in the study utilizing a wide variety of the data and theories acquired through books, the internet, newspapers, and other non-human resources that support research. 
Ismiarti,R.D., Yusuf,M. \& Rohmad,Z. (2019). Communication abilities of autistic children in social interaction .International Journal of Educational Research Review, 4(2),172-177.

\section{Data Analyses}

As disclosed Creswell (2015) in his book, qualitative data to the analysis is a process that involves organizing the data (text, transcript, images of data or photos), reading the introduction to the data base, coding, and organizing theme, the data presentation and interpretation of the data during the process of research. So it can be concluded that the analysis of the data in qualitative research starting from the collection of the data, systematically compiling the data, and interpret the data to others.

Steps in the analysis of the data qualitative according to Moleong (2014), among others:

1. The entire depth interviews with informants either record or tape. Recording interpreted in a typew ritten transcript of an interview that will be made in full.

2. Results typing viewed as a whole to see the full interviews from informants and do the editing process including writing and summarizing documents relevant to the theme of the research.

3. Researcher making coding, search for topics on the interview the which is the keyword to categorize reviews these topics fit within the research topic.

4. Classify by giving the code on the keywords that appear and categorize reviews those keywords. Categorization is the preparation category. Categories are groupings compiled on the basis of thoughts and opinions of informants and specific criteria.

5. Interpreting the data have been obtained by making a classification scheme for determining the theme.

6. Interpret each theme of the analysis results by comparing the results with the theme.

\section{RESULT}

As previously disclosed by Yuwono (2012) that limited communication skills of children with autism are very real, form three inclusive schools in ' $S$ ' city, each acquired one subject students with autism with each one special assistant teacher (GPK), the result as follows:

1. School A

a. FPA (autistic children), male gender, 11 years-old. FPA is able to communicate both ways, able to read through broken, gave a good response when called and asked to speak although sometimes the answer given does not match the question, the ability to write less, often FPA write letters upside down, it is still difficult to distinguish between the letter ' $b$ ' and ' $d$ ' and ' $\mathrm{f}$ ' and ' $v$ '.

FPA ability to invite others to interact normally starts with him greet a friend or a teacher then took a shake hand. FPA still avoiding eye contact when spoken to others, only a moment w ould FPA interlocutor's eyes, thereafter FPA will gaze at something that attracted him. Apart from that, FPA have a clear articulation of words, tone and tempo well. En glish space created by FPA when communicating and interacting with others is also good.

b. SH (special assistant teacher), according to communication and interaction SH owned FPA has been very good. Both the communication and interaction with friends as well as communication and interaction with the teacher. FPA dare to start an interaction, FPA is not afraid to invite his teacher or just to say hello and share hands with the word 'hi'. But despite FPA has the aspect of good communication and interaction, FPA still minus in terms of working together with his friend, if there are group activities, FPA still too preoccupied with their own ideas and imagination. For a sense of empathy and sympathy are also still lacking. For example, when a friend is nearby or incidentally fell in front of her friend and wounded, FPA there is no sense to immediately help, FPA more on curiousity why his friend had fallen, why the blood out of his legs, FPA does have the tone and tempo of a good talk, when communicating with others FPA less thrust his face (space either language), but not infrequently facial expression is not able to describe what is being communicated with others. But so far FPA be nice in a school, never once FPA clashed with her friends at school, either verbally or physically. Because if a condition or condition makes FPA less comfortable then FPA will dodge.

2. School B

a. DAB (autistic children), male gender and eight years-old. DAB able to communicate in both directions, but passive, do not dare to start an interaction, if you want to say something or have 
a desire to be pointing DAB. Less clear articulation of speech, cannot control the tone and tempo of speech, always avoid eye contact with other people or the other. DAB can be read even if haltingly and does not understand the meaning of a sentence. Space language created by DAB is still not good.

$\mathrm{DAB}$ proficient in memorizing a song, merely memorize without understanding their meaning, it cannot show facial expressions as a depiction of feelings.

b. AYP (special assistant teacher), according AYP two-way communication and interaction that occurs in DAB looks good when communicating and interacting with teachers, if his friend is still not good. It can be said it is rare for DAB seen interacting with his friend at school. Until the time of the observation, AYP has never completely initiate an interaction and communication with friends. For AYP is still some difficulty in dealing with DAB because in terms of communication DAB is still not very clear articulation and DAB are still avoiding eye contact when speaking, so that when DAB wanted something more often use non-verbal communication, by pointing or by pulling the hand teacher to show what is intended.

With what has been mentioned before, AYP said that in terms of communication are still far from good. So for sympathy, empathy, and cooperation can be said that DAB does not have all of them if by personal initiative, but when directed by the teacher, DAB still willing to share with his friends. Such a friend who did not snack for his lunch a few times lost or left behind, when the teacher asked DAB to give a bit of his lunch a few times occur DAB never refused to share lunch with his friends.

3. School C

FB (autistic children), female, 12 years-old. FB has not been able to start a communication and interaction with the environment, but for communication FB has been able to do in two directions. It can be said communications and interactions made by FB excellent, FB has yet to initiate a communication to create an interaction but when FB welcomed and invited to play with her friend $\mathrm{Fb}$ quickly once familiar, although the sentences uttered a word-a word not make him necessarily feel inferior. FB owned space nice language, she is also more often avoid eye contact. The tone and tempo of speech is also very good. It is just FB has emotional volatility, when no delight in anything FB does not hesitate to yell and vent her anger at that moment.

NDA (special assistant teacher) according NDA, as long as to be a teacher assistant of FB, FB is a pretty good kid in an academic. For interaction and communication with peers and teachers are good, although words in the phrase sentence but can respond to a conversation FB well. Every now and then is sometimes incoherent.

In terms of emotional control is still such a difficult thin for FB, NDA according to the thing could happen because FB is an only child and parenting given by her parents. When viewed from the everyday FB in school and what is brought to school can get a regular FB predictable that whatever the intention, what she was asking seemed to be met by both parents. Maybe that's what makes FB will be very explosive temper if the situation at the school makes it less pleasing.

In addition, the ability to communicate FB in terms of tone, tempo, and the room was very nice language. Just to be there was an interaction and communication, FB always waiting for her friend to her or greeted her first. Whether due stiff FB in greeting or simply because there is insecurity in themselves FB when should greet her friends beforehand.

In terms of communication, even have been able to communicate in both directions, but the communication skills possessed by children with autism in inclusive schools is still a passive communications and tend to avoid eye contact with the speaker.

1. On the first subject although it has been able to start an interaction and communication, after greeting with the word 'hi' is not necessarily the case a communication and interaction in a long time between the first subject with friends.

2. Subjects were actually able to communicate both more comfortable if you have to explain his desire to others by using non-verbal communication.

3. Third subject are able to perform two way communication and interaction with the well but could not get it started 
Ismiarti,R.D., Yusuf,M. \& Rohmad,Z. (2019). Communication abilities of autistic children in social interaction .International Journal of Educational Research Review, 4(2),172-177.

\section{DISCUSSION AND SUGGESTIONS}

From the observations of the research subjects it can be seen that although autistic teens have difficulties in social interaction so that their communication skills with the social environments have difficulties, they actually have a desire to interact, want a more intimate relationship with their friends, desire to contribute to their social environment, and strive to increase social aw areness.

In line with the above opinion, Darojat and Laksmiw ati (2013) show that although autistic a dolescents have passive patterns of social interaction with peers, they all assume that friendship is very valuable relationship that can add self-esteem and meaning to themselves. To create a good pattern of interaction, autistic adolescents need driving factors such as intermediaries, places, facilities, and moods or the will of autistic adolescents themselves.

Communication is a social activity. In a communication prosess there is a need for a social reciprocity, a reciprocal action between one person and another who interacts with each other. In autistic children, this reciprocal or reciprocal pattern of interaction usually does not occur (Schopler \& Mesibov, 1995).

Quoted from Azizah (2005: 137) the ability to communicate refers to the abilities that must be possessed by someone so that he can capture the message expressed by others and the ability to express ideas, thoughts, ideas, and feelings so that the message can be interpreted by others, both in utterance or writing.

Still quoting from Azizah (2005: 142) on verbal communication, the delivery of ideas, ideas, thoughts, and feelings is done verbally or verbally. This process is what we often call "talk". This can be seen from FPA and FB, both of them can communicate verbally even though they can halt well what they mean. FPA even though it can start a communication with its social environment but the chat created by FPA is not a long-term chat. As with FB, FB is the type that is shy to start an interaction but when someone invites him to talk, start a communication, it will create good interaction between FB and its social environment. Both FPA and FB when they have begun to lose their concentration, FPA and FB will lose emotional control and begin to be busy with themselves.

In non-verbal communication, the delivery of ideas, ideas, thoughts, and feelings is done using gestures or movements. This is what happens to DAB, the communication is passive, if not asked then DAB will tend not to talk. In fact, it is not uncommon when asked by DAB to only answer with a nod or shake his head. The articulation of his speech which is less clear makes FB point more often when he wants something.

Latifah (2012) revealed that the elements of social interaction are communication, while communication itself consists of two processes, namely receptive and expressive, both of which are included in the thought process of receiving stimulus and responding. While children with autism experience obstacles in this regard.

Interaction and communication in autistic children is not only a matter of two or more people, but also emphasizes how receptive and expressive processes are good and harmonious in the form of language symbols and body movements.

The results of this study indicate that the three research subjects indicated that communication created by autistic children in social interaction was still minimal. The three subjects did not have good concentration and meaningful eye contact in a communication engagement with their social environment.

\section{REFERENCES}

Agustin, I. (2016). Manajemen pendidikan inklusi di Sekolah Dasar Sumbersari 1 Kota Malang. Education and Human Development Journal, 1 (1).

Aissetiansya, T. (2015). Studi tentang pengaruh strategi visual terhadap kemampuan komunikasi anak autis di Sekolah Dasar Negeri Percobaan Surabaya. (Unpublished thesis). State University of Surabaya.

Azizah, N. (2005). Meningkatkan kemampuan berkomunikasi anak cerebral palsy. Jurnal Pendidikan Khusus, 1(2), 137-146 
Ismiarti,R.D., Yusuf,M. \& Rohmad,Z. (2019). Communication abilities of autistic children in social interaction .International Journal of Educational Research Review, 4(2),172-177.

Bottema-Beutel, K, et al. (2014). The role of supported join engagement and parent utterance in language and social communication development in children with autism spectrum disorder. New York: Springger Science+Business Media.

Chaplin, JP. (1999). Kamus lengkap psikologi. Jakarta: PT Grafindo.

Creswell, JW . (2015). Penelitian kualitatif dan desain riset. Yoggyakarta: Pustaka Pelajar.

Darojat, F. Z., \& Laksmiwati, H. (2013). Interaksi teman sebaya pada anak autis. Jurnal Pendidikan Khusus

Delphie, B. (2009). Pendidikan anak autistik. Yogyakarta: KTSP.

Denzin, N. K., \& Lincoln, Y. S. (2011). The introduction: The dicipline and practice of qualitative research. The Sage Handbook of Qualitative Research (Fourth Edition). Thousand Oaks, California: Sage.

Garnida, D. (2009). Sistem dukungan (supporting system) dalam penyelenggaraan pendidikan inklusif. Journal P4TK dan PLB.

Kustaw an, D. (2013). Manajemen pendidikan inklusif. Jakarta: Luxima.

Latifah, U. (2012). Interaksi sosial siswa autis (Studi kasus di kelas Inklusi SMPN 29 Surabaya). (Unpublished thesis). State Islamic Institute of Surabaya.

Marijani, L. (2003). Seputar autisme dan permasalahannya. Jakarta: Putrakembara Foundation.

Moleong, L. J. (2014). Metode penelitian kualitatif edisi revisi. Bandung: Remaja Rosdakarya.

Pratama, D. S. (2015). Metode Bermain Peran Boneka Tangan terhadap Kemampuan Komunikasi Sosial Anak Autis (Unpublished thesis). State University of Surabaya.

Rahayu, F. (2014). Kemampuan komunikasi anak autis dalam interaksi sosial. (Unpublished thesis). State University of Yogyakarta.

Schopler, E., Mesibov, G., \& Hearsey, K. (1995). Structured teaching in the TEACCH System. In E. Schopler \& G. B. Mesibov (Eds.) Learning and cognition in autism (pp. 243-268). New York, NY: Plenum.

Sembiring, C. E. (2014). Komunikasi antarpribadi pada anak penderita autism. (Unpublished thesis). State University of North Sumatera.

Smith, J. D. (2014). Sekolah inklusif konsep dan penerapan pembelajaran. Bandung: Nuansa Cendekia. 